\title{
BAILES BOLEROS Y FLAMENCOS EN LA PINTURA COSTUMBRISTA SEVILLANA
}

\author{
BOLERO AND FLAMENCO DANCES IN SEVILLIAN \\ COSTUMBRISTA PAINTING
}

\author{
Rocío Plaza Orellana \\ Universidad de Sevilla. España \\ ORCID: 0000-0002-2206-393X \\ rplaza@us.es
}

\begin{abstract}
Entre 1840 y 1860 se produce uno de los periodos más prósperos de la pintura sevillana. Apareció un nuevo tema, el de las composiciones de bailes. Se desarrolló un mercado nacional e internacional que las demandaba en óleos, acuarelas y litografías. Su creación se produjo por la existencia de un público que disfrutaba los bailes boleros y flamencos en fiestas privadas, organizadas por maestros de baile para atender a una creciente demanda turística.

Palabras claves: pintura costumbrista; bailes boleros; bailes flamencos; Sevilla; siglo XIX.
\end{abstract}

Between 1840 and 1860, one of the most prosperous periods of Sevillian painting took place. A new theme appeared, that of the dance compositions. A national and international market was developed that demanded them in oil paintings, watercolors and lithographs. Its creation was produced by the existence of an audience that enjoyed bolero and flamenco dances at private parties, organized by dance masters to meet a growing tourist demand.

Keywords: costumbrista painting; bolero dances; flamenco dances; Seville; $19^{\text {th }}$ century.

\section{FLAMENCO Y PINTURA ENTRE 1840 Y 1860}

A lo largo de la década de 1840 comienza la cristalización del espectáculo flamenco en la ciudad de Sevilla. En estos años, este proceso de creación transcurre en paralelo al desarrollo de un mercado pictórico de pintura costumbrista de temática de bailes preflamencos y boleros que coinciden en su iniciación y en su evolución. Esta coincidencia se debe a la aparición de consumidores de bailes, un público que hizo posible, con su inversión económica y su demanda, la aparición de espacios preparados para la exhibición de estos espectáculos; así como el surgimiento de artistas y de una cadena de agentes capaces de encontrar el aliciente 
económico preciso para mantenerlo y ajustarlo a las necesidades que sus espectadores demandaban. Los tradicionales pasos de la escuela bolera se ofrecieron con regularidad en los teatros de Sevilla desde que el primero de ellos, el Cómico, abriera sus puertas en 1795; sin embargo, la presencia en la ciudad de una sólida y eficaz corriente conservadora contraria a la exhibición de los mismos, así como a la propia existencia del teatro, impediría la evolución de otros bailes de carácter popular, como es el caso de bailes como la cachucha, el olé o el vito. Estos, no obstante, tendrían una presencia testimonial en ocasiones en el teatro ${ }^{1}$, que si bien se reveló incapaz de incentivar a los espectadores desde la escena, resultó útil para comprender su existencia en la ciudad, así como su mantenimiento, reservado a espacios privados y a fiestas particulares con una exhibición casi secreta, como veremos más adelante.

Estos pasos preflamencos continuarían su enseñanza y su evolución en la ciudad, invisibles a las escenas oficiales, guarecidos en arrabales como Triana o la Macarena, y apartados de la vista de los visitantes extranjeros, que desde finales del siglo XVIII consumían habitualmente fandangos, seguidillas y boleros en el teatro Cómico sevillano. La pérdida de poder político de las corrientes conservadoras teñidas por el desprecio hacia los bailes y el teatro en la ciudad, la irrupción de las políticas liberales, la llegada de numerosos profesionales extranjeros residentes para participar en su modernización, las transformaciones de la censura sobre la escena, y la llegada incesante de viajeros a Sevilla, atraídos no solo por el patrimonio artístico sino sobre todo humano, debido a las inquietudes creadas por el romanticismo, dirigirán la atención hacia este tipo de bailes. Por ello, al consumo habitual en los teatros de los pasos de la escuela bolera, vendría a sumarse el interés por estos bailes populares que presentaban a los espectadores con el atractivo de su reciente aparición tras las prohibiciones y las persecuciones previas.

De esta forma, el incremento de espectadores en un caudal constante y regular, provocó en 1845 la aparición del primer espacio conocido hasta el momento para el consumo exclusivo de espectáculos de bailes de palillos, boleros y pasos flamencos, gracias a la iniciativa del maestro de bailes Miguel de la Barrera ${ }^{2}$. Se

${ }^{1}$ En el Teatro Principal de Sevilla aparece el olé por primera vez el 24 de diciembre de 1807, ejecutado por Luisa Cañete, repitiéndolo posteriormente Rafaela Exprás el 24 de diciembre de 1812. Posteriormente, durante el gobierno de Fernando VII, consta documentalmente tan solo su ejecución en una ocasión, el 19 de enero de 1813, en medio de un gran alboroto. A partir del 31 de enero de 1836 su presencia se normalizó en las carteleras de los teatros de Sevilla, reflejando su popularidad, aunque en las fiestas organizadas lejos de las salas se mantuvo de una forma ininterrumpida. PLAZA ORELLANA, Rocío: El Flamenco y los románticos. Un viaje entre el mito y la realidad. Sevilla, 1999, pp. 301, 722-724 y 734-743.

2 Ibidem, pp. 654-667; y PLAZA ORELLANA, Rocío: Anotaciones y cartas del pintor Egron Lundgren en Sevilla. Sevilla, 2017, pp. 61-63. 
trató de la primera academia de bailes de Sevilla, a la que en cuestión de muy pocos años se le añadieron otras, como las de Manuel de la Barrera ${ }^{3}$, Amparo Álvarez "la Campanera"4 o Luis Botella, todas en funcionamiento entre 1845 y 1860. A estas salas de espectáculos de horarios y calendarios regulares en este momento, se le sumaría un amplio elenco de espacios alternativos que vino a suplir la creciente demanda, diversificada en públicos e intereses, lo que desembocó en la aparición de nuevos bailes, en la evolución constante de los mismos y en un espectáculo en permanente transformación, debido a la multiplicación de la oferta y a la competencia entre empresarios, cicerones y artistas.

El público que hizo posible el asentamiento de estos bailes, como los jaleos, estaba constituido por extranjeros, especialmente británicos, tanto residentes como ocasionales, y trasladó con su viaje dos hábitos importantes. Por un parte, demandaría en la ciudad el espectro de consumo que venían desarrollando hacia productos derivados de la experiencia teatral, que se tradujo en la adquisición de prendas y complementos de baile - chaquetillas, fajines, zapatillas, mantones, sombreros, castañuelas, abanicos-, contribuyendo con ello también a la aparición de la industria del souvenir en estos años en Sevilla ${ }^{5}$; y, por otra, reclamaría imágenes sobre la experiencia disfrutada, en la línea que los británicos venían desarrollando desde finales del siglo XVIII con las representaciones compositivas al óleo de importantes escenas del repertorio shakespeariano ${ }^{6}$, así como concretamente con las escenas de danza sobre litografía de procedencia francesa, desarrolladas a lo largo de la década de 1830, gracias a la importación de estampas y a la creación de imágenes propias del repertorio escénico londinense siguiendo la línea francesa $^{7}$. De esta forma se activó una demanda que en 1840 no encontró acomodo inmediato en la ciudad, pero que en apenas cinco años ya ofertaba todo lo que se solicitaba, es decir, souvenirs de baile en las tiendas, listos para llevar e imágenes de los bailes consumidos en la ciudad. En este ambiente económico y social, los bailes emergieron y se desarrollaron hasta consolidarse en una constante evolución con permeabilidad y eficacia, adaptándose a aquello que reclamaban quienes

${ }^{3}$ PLAZA ORELLANA, Rocío: Los bailes españoles en Europa. El espectáculo de España en el siglo XIX. Córdoba, 2013, pp. 292-293.

${ }^{4}$ ORTIZ NUEVO, José Luis: ¿Se sabe algo? Viaje al conocimiento del Arte Flamenco en la prensa sevillana del XIX. Sevilla, 1990, pp. 37-38.

5 PLAZA ORELLANA, Rocío: Recuerdos de viaje. Historia del souvenir en Andalucía. Sevilla, 2012, pp. 80-84.

${ }^{6}$ SHAWE TAYLOR, Desmond: Dramatic Art. Theatrical paintings from the Garrick Club. Londres, 1997.

7 Concretamente, en la construcción de la imagen de la bailarina del ballet francés de este periodo, considerado el "cenit" o de mayor esplendor, enmarcado entre 1830 y 1850 , participarían los litógrafos Alfred Edward Chalon, Pierre-Louis Grévedon, Achille Devéria, J. Bouvier, Herbert, Brandard, Novello, Lynch, Francis Deffett, Child, Marie Alexandre Alophe, Blanc, Camaret, Battistelli, Maguire, Léon Noël, Valentini o Guérard. 
pagaban entradas para su consumo; y con ello también, en paralelo, como evidencian las coincidencias en las fechas, a la proyección de la experiencia a través de otros objetos de consumo, entre ellas la pintura de bailes.

Cuando surge en 1845 la primera academia de bailes, se trata del primer espacio en la ciudad dedicado exclusivamente a los espectáculos de danza, sin interferencias provenientes de ninguna otra arte escénica que no fuera complementaria. Responde a una demanda que estaba sin cubrir hasta el momento, ya que los bailes se ofrecían ubicándose en todo tipo de espacios alternativos alquilados o preparados para la ocasión. Por ello, la apuesta económica realizada en la creación de esta academia evidencia la existencia de un público dispuesto a disfrutarlos previo pago de una entrada; de la rentabilidad de un negocio que continuó su curso permitiendo la apertura de otras salas similares; y la solidez de una cadena de intereses que se enlazaban desde los artistas, hacia los intermediarios, y desde estos hacia las empresas de los hoteles, donde residía el público dispuesto a costearlos. Sería también a partir de estos años que median entre 1845 y 1850 cuando comienza realmente a forjarse la pintura de bailes, entendida como una composición más allá de un retrato de bailarina o bailarín posando con su indumentaria.

En 1849, cuando el pintor Egron Lundgren llegó a Sevilla, encontró dos talleres principales de pintura: el de Joaquín Domínguez Bécquer y el de Antonio Cabral Bejarano. Para el primero traería cartas de recomendación, por lo que a partir de este contacto pudo establecer relación con el núcleo de pintores locales de la ciudad. Sería precisamente en ese momento cuando comenzaba a emerger el género, destacando dentro de la producción local los trabajos realizados al respecto por Joaquín Domínguez Bécquer ${ }^{8}$ y Manuel Rodríguez de Guzmán, principalmente ${ }^{9}$. Ambos comenzarían a desarrollar una interesante labor en la creación de escenas compositivas de bailes, ubicándolos en unos ambientes festivos salpicados de espectadores y de artistas dentro de unos espacios ideados principalmente a partir de los entornos señalados por la literatura de viajes británica y francesa de esos años. Espacios, en cualquier caso, vinculados a otras escenas pintorescas.

En paralelo se desarrollaría también la labor pictórica de cuatro importantes artistas extranjeros que tendrían estudio propio en la ciudad. Son los casos de Phillip Villamil a partir de $1847^{10}$, Egron Lundgren entre 1849 y 1853, Alfred Dehodencq en 1850 y John Phillip en 1852. Los cuatro producirían pinturas de bailes desde diferentes técnicas que encontrarían una importante proyección en

${ }^{8}$ VALDIVIESO, Enrique y FERNÁNDEZ LÓPEZ, José: La pintura romántica sevillana. Sevilla, 2011, pp. 93-97; y RUBIO JIMÉNEZ, Jesús y PIÑANES GARCÍA-OLÍAS, Manuel: Joaquín Domínguez Bécquer. El guardián del Real Alcázar de Sevilla, Sevilla, 2014.

${ }^{9}$ MÉNDEZ RODRÍGUEZ, Luis: Manuel Rodríguez de Guzmán. Sevilla, 2000.

10 AlCOLEA AlBERO, Fernando: El pintor Phillip Villamil of Jamaica (18141878). Create Space Independente Publishing, 2014, p. 31; y PLAZA ORELLANA, Rocío: Egron Lundgren. Un pintor sueco en Sevilla. Sevilla, 2012, pp. 137-139. 
compradores extranjeros. Los cuatro contribuirían a la creación de estas escenas compositivas, pues producirían iconografías nuevas, ante la necesidad de suplir la demanda inmediata. Las imágenes creadas por estos hombres que provenían de formaciones dispersas, desde las academias de bellas artes de sus países de origen hasta los telones de teatros, resultarán fundamentales para comprender la evolución de la pintura de costumbres de este género entre los artistas locales. En cualquier caso, no es el interés de este estudio desgranar el proceso de creación de la pintura de este género en sí por los pintores locales y extranjeros mencionados, ni el de determinar el caudal de influencias mutuas que la hicieron posible, sino el de destacar el interés de este tipo de pinturas en su relación con las experiencias vividas en los bailes que ofertaba la ciudad. En esta línea es preciso considerar un punto de partida: muchas de ellas son el resultado de una imagen vinculada, no solo a bailes concretos que conllevaba el uso de indumentarias precisas, pues suele ser siempre el caso, sino también a artistas retratados y a espacios reconocibles en su exhibición.

\section{LOS BAILES BOLEROS}

Desde que el teatro Cómico abriera sus puertas en Sevilla el sábado 17 de octubre de $1795^{11}$, el repertorio de bailes que ofreció durante los entreactos de sus comedias y dramas procedió mayoritariamente de la escuela bolera. De este modo las diversas variaciones de la tríada habitual, constituida por boleros, seguidillas y fandangos, se repetían noche tras noche en las funciones ordinarias, y en las especiales dedicadas al beneficio de la compañía. La existencia de una sólida y eficaz corriente conservadora en la ciudad encabezada por el ideario del influyente fraile Diego José de Cádiz, veinticuatro honorario del ayuntamiento de Sevilla, mermó la proyección de otros bailes populares, como es el caso de la cachucha o el olé, que se ofertaron en teatros como los de Cádiz, Madrid o Barcelona desde los años finales del siglo anterior y los primeros del XIX. A la existencia de su habitual censura se sumaba la fuerza de una opinión pública fortalecida desde algunos sectores del poder municipal, que se cimentaba sobre los principios de inmoralidad que este religioso extendía sobre las comedias, los bailes o las modas femeninas, aspectos todos fundamentales para el desarrollo del espectáculo de la danza, por lo que trajo como consecuencia una muesca en la evolución escénica de esos pasos populares, entre los que se contaban los bailes de jaleo, que se vieron reducidos en el espacio y en el tiempo.

Por este motivo, las pinturas de bailes o de bailarines que se realizaron en la ciudad de Sevilla durante los primeros cuarenta años del siglo XIX representan en

${ }^{11}$ AGUILAR PIÑAL, Francisco: Sevilla y el teatro en el siglo XVIII. Oviedo, 1974, p. 187. 
su mayor parte pasos de esta escuela. Bailes que tienen la particularidad de realizarse en pareja, de contar con una gran diversidad de mudanzas que se plasman en sus aspectos más vistosos, de bailarse con tres tipos de calzados diferentes, según el paso, y que se acompañan con castañuelas en las manos. La continuidad de los boleros, fandangos y seguidillas en el repertorio teatral de entreactos motivó su prolongación en la pintura de bailes también a partir de 1840, conformando parte de las composiciones del nuevo género. Los bailes en parejas con castañuelas en las manos se convierten en los principales recursos pictóricos a los que recurre el pintor para indicarnos que nos encontramos ante uno de ellos. Si bien continuaron su curso, prolongándose hasta cerrar la década de 1860, lo cierto es que fueron perdiendo el interés de los espectadores, tanto nacionales como extranjeros. El marco temporal que se abre desde que llegara a la península Ibérica Alejandro Dumas durante el otoño de 1846 hasta que lo hiciera su compatriota Charles Davillier en 1862 refleja su progresivo decaimiento, así como la aparición de pasos boleros nuevos.

Davillier, amante de los bailes españoles, dejaría a sus futuros lectores el testimonio más claro de la ausencia de estos antiguos pasos que poblaban la literatura de viajes francesa hasta entonces. Al enumerar los bailes que se podían disfrutar en aquel momento y que más adelante veremos, escribía que "casi todos los pasos que hemos nombrado anteriormente se bailan también en los teatros españoles. Hay otros dos, el bolero y el fandango, que gozaron antaño de gran favor y que hoy, salvo raras excepciones, solo se bailan en los patios" 12 . Aseveración que repetiría en varias ocasiones, al referirse a los bailes de su tiempo, concretamente a los de las décadas de 1860 y 1870: “después de treinta o cuarenta años el fandango ha sido un poco abandonado"13. De esta manera, el repertorio habitual que había dominado la escena durante las tres primeras décadas del siglo XIX en los teatros de Sevilla, iría desapareciendo a medida que avanzó el siglo, para poblarse de otros bailes. Pero ni los bailarines ni el pueblo los habían olvidado, por lo que cuando acudían a fiestas particulares en las que ellos eran parte integrante del sostenimiento económico de la diversión, los artistas se los cantaban y bailaban en medio del nuevo repertorio que acostumbraban ${ }^{14}$. Por ello pasaron a la pintura de bailes de este tiempo, porque continuaban vivos a través de la literatura de viajes editada en las cuatro primeras décadas en Inglaterra o Francia, ya que sus lectores los solicitaban en las fiestas de pago que se organizaban en alguna academia o en cualquier otro salón preparado para la ocasión.

Los bailes de la escuela bolera, también de este periodo, aparecen representados en pinturas como el Baile en el interior de una posada, de 1841, de Joaquín Domínguez Bécquer, de la colección de Carmen Thyssen Bornemisza de Madrid, importante por la temprana fecha de su producción; el Baile en una

${ }^{12}$ DAVILLIER, Charles: Viaje por España. Vol. 2. Madrid, 1988, p. 502.

13 Ibidem, pp. 480-481.

14 PLAZA ORELLANA, Rocío: El Flamenco y los románticos..., op. cit., pp. 631-632. 
bodega, de Joaquín Domínguez Bécquer, fechado en 1844, relevante por formar pareja probablemente con otra pintura llamada Baile en una posada de la misma fecha de una colección particular ${ }^{15}$, que tiene la particularidad de ofrecer el otro tipo de baile, el de jaleos (Figuras 1-2).

Los tipos de majos con sus atuendos tradicionales, especialmente masculinos, concebidos a partir de las creaciones de José Domínguez Bécquer principalmente, pasaron a convertirse en la indumentaria de los bailarines. Y las bailarinas se ataviaron, bien con la indumentaria tradicional compuesta de saya blanca, o bien con los modelos derivados de los trajes creados por las modas parisinas ${ }^{16}$. Dentro de esta línea destaca, por ejemplo, la descripción de una de las fiestas populares más importantes descritas en un libro de viajes durante el gobierno de Fernando VII en Sevilla, la que menciona el profesor alemán Victor Aimée Huber, celebrada en Triana durante el mes de marzo de 1822, al que titula "The Flash House in Triana" ${ }^{17}$. Se trata de un texto con diversas traducciones desde su primera publicación, por lo que resulta relevante para el conocimiento de algunos testimonios posteriores, como es el caso del ofrecido por Richard Ford. En este texto, concretamente en el editado en 1837 en Gran Bretaña, se narra una escena de baile en una casa de Triana sobre la que nos informa que destacaba su aspecto ruinoso y sombrío ${ }^{18}$. El patio se convierte en el lugar de la fiesta, y en él "un numeroso grupo se había reunido alrededor de una pareja que estaba bailando el fandango al sonar de una guitarra y el repiqueteo de unas castañuelas, entre los ruidosos aplausos de los espectadores" ${ }^{\prime \prime}$. A través de esta descripción, que posiblemente se trate de la referencia más relevante y antigua que poseemos sobre estas escenas en Sevilla dentro de la producción editorial británica, conocemos que durante esta etapa del gobierno fernandino los bailes que acostumbraron a bailarse en espacios privados son principalmente los fandangos, como acreditan también otros viajeros, así como que los espacios habituales no escénicos son grandes casonas en un estado de conservación pésimo con patio.

${ }^{15}$ RUBIO JIMÉNEZ, Jesús y PIÑÁNEZ GARCÍA-OLÍAS, Manuel: Joaquín Domínguez Bécquer..., op. cit., pp. 142-143.

${ }^{16}$ PLAZA ORELLANA, Rocío: Historia de la moda en España. El vestido femenino entre 1750 y 1850. Córdoba, 2009, pp. 156-173.

${ }^{17} \mathrm{El}$ texto se publicó en Gottingen entre 1828 y 1833 en dos volúmenes, con la referencia: HUBER, V. A.: Skizzen aus Spanien. 2 vols. Gottingen, 1828-1833; a lo largo de esta publicación, concretamente en 1830, vería la luz una edición en Bruselas en francés: HUBER, V. A.: Esquisses sur l'Espagne, traduit de l'allemand par Louis Levrault. 2 vols. Bruselas, 1830; junto con otra en París en 1830: HUBER, V. A.: Esquisses sur l'Espagne, traduit de 1'allemand par Louis Levrault. 2 vols. París, 1830. Finalmente sería traducida al inglés en 1837: HUBER, V. A.: Stories of Spanish Life, from the german of Huber. 2 vols. Londres, 1837.

${ }^{18}$ HUBER, Victor Aimée: Stories of Spanish Life, op. cit., p. 6.

19 Ibidem. 
Al concluir el gobierno fernandino, irrumpir la regencia de María Cristina e iniciarse los primeros años del gobierno de la reina Isabel, se visibilizan definitivamente en Sevilla los bailes que constituirían el núcleo primordial que alimentará al flamenco: los bailes de jaleos. Estos contaminarán a su vez el repertorio tradicional, es decir, provocarán transformaciones en los pasos boleros, tanto en sus pasos y mudanzas como en sus figuras. Los ejemplos de esta situación la encontramos de nuevo en estrecha relación con los testimonios que nos ofrece la literatura de viajes y la pintura, unidas ambas por la demanda del mercado. La agitación y la sensualidad como rasgos primordiales de su ejecución, junto con la peculiaridad del predominio del baile de mujer, característicos de pasos como el olé, el vito o el jaleo de Jerez, contaminarán a los antiguos boleros, creando variaciones tan interesantes como las boleras robadas o las boleras jaleadas que pasarán a la pintura. Este proceso de implantación de unos, evolución de otros y desaparición de la escena pública de algunos, se produjo en este periodo que media entre 1840 y los últimos años de 1860, debido a la multiplicación de la demanda extranjera que desembocó en la aparición de nuevos espacios para su consumo, y de nuevos bailes.

Este proceso encontró en la pintura sevillana su reflejo en la aparición de temas compositivos en entornos específicos vinculados a ellos, bien por la literatura, bien por su propia exhibición en sus ambientes festivos, y que tendría entre sus principales exponentes por su capacidad creativa a Joaquín Domínguez Bécquer, Manuel Rodríguez de Guzmán y Manuel Cabral Bejarano, en consonancia con los trabajos pictóricos de los extranjeros Phillip Villamil, Egron Lundgren, Alfred Dehodencq y John Phillip, residentes en estos años finales de 1840 y primeros de 1850 en Sevilla.

La narrativa del viaje que escribió Charles Davillier junto con los dibujos de Gustave Doré, editados en 1874, se convierte en el principal testimonio sobre los espectáculos de bailes al iniciarse la década de 1860. Los tipos de bailes, la técnica, la indumentaria de los bailarines, el origen de los pasos, los espacios en los que transcurren estas fiestas, su ambiente social, el precio que se pagaba por asistir a ellas y el proceso para poder llegar a formar parte de su público aparecen recogidos pormenorizadamente en su libro L'Espagne. Davillier cuenta cómo le entregaron en su hotel un cartel impreso en papel rosa donde el maestro Luis Botella anunciaba el espectáculo que tendría lugar en su academia. En la línea de los extractos de anuncios que ofertaban los maestros de bailes de las diferentes academias en los diarios sevillanos El Porvenir o La Andalucía en estos años, se repite la misma estructura. Se anuncian danzas "nacionales y andaluzas" 20, se destaca que serán ejecutados por "boleras", y, de darse el caso de su participación, se menciona la presencia de la artista demandada por los viajeros británicos a partir de 1853: Amparo Álvarez "la Campanera". Finalmente se desglosa el repertorio de bailes, que en este caso fueron "seguidillas, bolero, manchegas, mollares,

${ }^{20}$ DAVILLIER, Jean Charles y DORÉ, Gustave: Viaje por España..., op. cit., pp. 481-482. 
boleras de jaleo, la jácara, olé, polo del contrabandista, olé de la curra, jaleo de Jerez, malagueñas del torero, boleras robadas, jota, vito, gallegada y los panderos acompañados a la guitarra" ${ }^{21}$. En definitiva, nos encontramos un repertorio constituido por bailes en los que se alternan los pasos de la escuela bolera tradicional, con los que se abre el espectáculo a modo de obertura, con bailes de jaleos, olés y vitos, y nuevos pasos creados por los maestros de academia como el de la malagueña y el torero, o nacionales, como la jota. Todos con palillos, y destacando su ejecución por mujeres, bien en pareja en los boleros, bien a solas.

Reflejo de esta influencia entre ambos es la ejecución del bolero que se anunciaba y que sería ejecutado por dos mujeres, en lugar de por la pareja habitual del bolero tradicional compuesta por un bailarín y una bailarina ${ }^{22}$. Un paso que en 1845 había visto ejecutar el escritor británico Terence Hughes en Sevilla en una de estas fiestas, destacando precisamente por un beso robado entre los bailarines durante el baile: "La bolera ha mantenido su ascendencia en el escenario español más allá de todos los competidores; y la más fascinante de esta clase es la Bolera Robada, al final de la cual el zagal asalta sin ceremonias un beso"23. La traslación pictórica de este baile, y concretamente también de este proceso de hibridación que se está produciendo debido al interés que muestran los extranjeros por elementos como los bailes femeninos, la sensualidad y un ritmo frenético en los movimientos, es la pintura atribuida a Manuel Rodríguez de Guzmán del Museo de Bellas Artes de Sevilla titulada Boleras del beso, fechada hacia 1850. En ella se recoge concretamente el paso de las "boleras robadas", ya presente en los salones de baile desde 1845, donde apreciamos el bolero interpretado por una pareja de mujeres, tal y como la vio Charles Davillier en 1862. Hugues, que evidencia a lo largo de su texto conocimiento, y sobre todo interés por los bailes de España, pues informa a sus lectores de aquellos que se están produciendo en Sevilla en 1845 y todavía se desconocen en Londres, nos ofrece el documento que refleja esta traslación de ritmos y de dinamismo entre los bailes de jaleos y los tradicionales boleros. Y lo hace informándonos acerca de otro bolero desconocido en Londres, es decir, de reciente exhibición en Sevilla posiblemente, llamado las "boleras jaleadas". Sobre ella nos informa: "Una curiosa variedad de Bolera aún no conocida en Inglaterra, es la Bolera Jaleada, en la que los espectadores animan a los bailarines con sus voces, como los deportistas españoles animan a sus perros con gritos. El tiempo está marcado y los pasos se acompañan de un alto y fuertemente aspirado Hal, lal, la, lal!, como si fuera a alentar a los figurantes a mayores esfuerzos, y el efecto que produce la unión de la numerosa audiencia en un grito es de lo más destacable"24 (Figura 3).

${ }^{21}$ Ibidem, p. 482.

${ }^{22}$ Ibid., p. 485.

${ }^{23}$ HUGUES, Terence: Revelations of Spain in 1845. Vol. 1. Londres, 1845, p. 413.

${ }^{24}$ Ibidem. 
Todo esto se traduce en la construcción de composiciones pictóricas en las que prima el dinamismo a través de la figura fijada de la bailarina o bailarines en su paso, y también de quienes constituyen el cuadro con sus expresiones, colorido y animación. Un nerviosismo que se deriva de las sensaciones transmitidas por este tipo de espectáculos producidos en fiestas privadas creadas para extranjeros, en las que dominan composiciones centradas en unos bailes donde las antiguas mudanzas habituales de los pasos boleros, serían sustituidos por los meneos, zarandeos, zapateos de los bailes de candil, cascabel gordo o botón "goro" que se produjeron entre los años finales del siglo XVIII y los primeros del XIX; pasos que se convertirían en el germen de los bailes flamencos como el olé, el vito o los jaleos como el de Jerez, el zorongo, etc. Una traslación que se produjo al calor del negocio que alimentaron los extranjeros en su consumo privado de fiestas particulares en salones alquilados y academias de baile desde los primeros años de la década de 1840, y que produciría no solo unos bailes antiguos transformados en aspectos y estructuras, sino también toda una legión de pasos nuevos. Esta novedosa riqueza creativa trasladaría su posterior demanda a la pintura, y marcaría la aparición de un mercado en Sevilla, donde se reclamaba la plasmación del conjunto de sensaciones sensuales, vibrantes, enérgicas, estremecedoras y voluptuosas que generaban las bailarinas y el ambiente catártico que los envolvía. Un ambiente en el que se encontraban envueltos quienes serían sus primeros compradores, los británicos, y por el que no asomaban en 1845 ni en 1860 las clases burguesas ni aristocráticas sevillanas, más que ocasionalmente. El pintor sueco Egron Lundgren evidencia esta realidad, pues cuenta que, a partir de su primera venta a un británico de una escena de baile, estos se convirtieron en su principal clientela ${ }^{25}$.

El proceso de hibridación de los bailes conllevó una transfusión de elementos desde los pasos tradicionales boleros hasta los bailes de jaleo y viceversa, que no es el caso analizar en este estudio. Sin embargo, resulta imprescindible establecer las diferencias entre ambos para comprender las iconografías que se crearon en la pintura para identificarlos. Curiosamente resulta más fácil encontrar las diferencias en las imágenes pictóricas que se crearon en estos años, que en los propios testimonios literarios sobre bailes, a juzgar por las descripciones que poseemos de sus espectadores, especialmente procedentes de la clientela inglesa y francesa. A través de las memorias de numerosos viajeros nos encontramos un panorama interesante pero muy confuso, por la rapidez con la que los pasos utilizaban recursos que funcionaban entre el público y los repetían en pasos diferentes. Por ello, las diferencias entre los bailes boleros y los de jaleo literariamente se encuentran en su ejecución en pareja, y en el uso de las castañuelas. Sin embargo, este último aspecto no siempre es contundente, pues se cuentan casos del uso de castañuelas en bailes de jaleo en

${ }^{25}$ PLAZA ORELLANA, Rocío: Egron Lundgren..., op. cit., pp. 143 y 147. 
las descripciones de estos bailes ${ }^{26}$. Por ello existe una iconografía concreta que diferencia los bailes de jaleos, y que fue creada en paralelo con la evolución de los mismos como espectáculos particulares de salones, precisamente para distinguirlos de los demás, debido a la confusión que se generaba entre los propios espectadores extranjeros principalmente, por la cantidad de cambios que experimentaron en muy poco tiempo por los préstamos que se tomaron entre ambos. Es decir, por la hibridación que se produjo debido a las expectativas generadas por los pasos de la escuela bolera -boleros, seguidillas y fandango- alimentada a través de la literatura de viajes previa a 1840, que reclamaba verlos en esos espacios aunque estuvieran cayendo en desuso, y por el atractivo que ofrecían los de jaleos más acordes con las necesidades emocionales de aquellos tiempos.

Parte de la complejidad y de la confusión que genera la identificación de estos bailes, con respecto al amplio repertorio en el que se mueven, radica principalmente en la literatura de viajes y memorias escritas por sus consumidores en este tiempo. No siempre su testimonio es todo lo clarificador que sería deseable, a lo que se suma que a veces se producen casos confusos también en la comprensión del texto en la traducción. Un ejemplo de ello radica precisamente en la traducción al castellano del libro L'Espagne publicado por Charles Davillier con ilustraciones de Gustave Doré en 1874. Davillier, un perfecto conocedor de la escena española desde 1861, y quien con más profusión e interés ha escrito sobre los bailes españoles y andaluces del segundo tercio del siglo XIX, nos informa que a diferencia de los boleros que se representan en el teatro, que se bailan habitualmente por varias parejas: "en las reuniones particulares se baila con más frecuencia a dos"27.

El dibujo con el que Gustave Doré ilustra el comienzo del capítulo catorce, dedicado a los bailes, retrata a una mujer bailando sola con un sombrero a los pies, jaleada por un grupo de hombres con guitarra, pandero y violines sujetándose el vestido con ambas manos y sin castañuelas. A los pies aparece en francés el texto: "le bolero (p. 396)" "28. En él remite a la página en la que Davillier explica las particularidades del baile, pero en ella no se hace alusión alguna a que se tratara en ningún momento de un baile de una mujer sola, sino en su versión más reducida de un baile de pareja, por lo que se produce una confusión derivada posiblemente de un error de la primera edición francesa que se ha ido repitiendo a lo largo de las sucesivas ediciones. Es decir, que el dibujo de Doré no se corresponde ni con el pie de imagen que le han escrito, pues no representa un bolero sino un baile de jaleo como veremos a continuación, ni tampoco corresponde la imagen con la información que

${ }^{26}$ DAVILLIER, Jean Charles y DORÉ, Gustave: Viaje por España..., op. cit., pp. 485-486; y HUGUES, Victor Aimée: Revelations..., op. cit., p. 417.

27 "Au théátre, le boléro est ordinairement dansé par plusieurs parejas ou couples, mais dans les réunions partieuliéres on le danse le plus souvent à deux". DAVILLIER, Charles: L'Espagne. París, 1874, p. 396.

${ }^{28}$ Ibidem, p. 368. 
Davillier ofrece sobre la ejecución de este baile en teatros y fiestas privadas en la página 396 de la primera edición a la que remite ${ }^{29}$. Para aumentar aún más la confusión generada por este error primero de edición en su texto original, se añade el cometido reiteradamente en la traducción al castellano en diversas ediciones. La traducción realizada de este fragmento expresa que el bolero en las reuniones particulares "lo suele bailar una sola bailaora" 30 , atendiendo más al grabado de Doré que encabeza el capítulo como explicación, que al propio texto al que remite el pie de la misma imagen. Una imagen que, como ya se ha explicado anteriormente, no corresponde a un bolero sino más bien a un baile como el olé o el vito por un error en la primera edición realizada en París en 1874 por Coreble, Crété Fils.

Las faldas levantadas con la mano para dejar ver las enaguas, los sombreros masculinos por el suelo a los pies de la bailarina o colocado sobre su cabeza, y las manos despojadas de castañuelas, son elementos con los que los pintores locales y extranjeros construyeron la iconografía de los bailes de jaleos, completamente diferentes de los tradicionales boleros de origen dieciochescos. Y a ellas responde esta imagen que tanta confusión genera en la primera edición de Davillier, y que no tiene traducción pictórica ninguna en las pinturas de baile producidas en Sevilla en este tiempo vinculadas al bolero.

Otra de las grandes diferencias que marca el baile y el ambiente son precisamente los instrumentos musicales de acompañamiento. Los boleros en estas academias se acompañaban de los palillos que portaban las artistas, y del violín principalmente, así como de la guitarra puntualmente. Lo que acontece en el baile al que asiste Davillier en el Salón del Recreo de la calle Tarifa número 1 era bastante habitual en este tipo de espectáculos, la sustitución del violín reservado para los boleros de pareja, por la guitarra en los pasos de jaleos ${ }^{31}$. Si bien el violín también acompañaba en estos espacios a estos bailes de mujer sola, como reflejan numerosos testimonios de clientes, no parece que fuera del gusto de quienes debían animar y acompañar la fiesta, quienes imponían la guitarra para su ejecución. Este es un detalle que nos revela el corpus instrumental que participó en la creación de estos bailes desde sus orígenes hasta que irrumpió como un espectáculo con clientela de taquilla, compuesto en las fiestas particulares por la percusión y la guitarra, y en las academias o salones de baile por los instrumentos habituales del teatro, como es el caso del violín.

\section{LOS BAILES DE JALEOS. EL VITO Y EL OLÉ}

La estampa de una mujer sola sujetando un extremo de su saya con una mano o bien con las dos, según el movimiento del baile, mostrando sus pantorrillas y

\footnotetext{
${ }^{29}$ Ibid.

${ }^{30}$ DAVILLIER, Charles y DORÉ, Gustave: Viaje por España..., op. cit., vol. 1, p. 502.

${ }^{31}$ Ibidem, p. 486.
} 
sus enaguas blancas; el tocado de un sombrero calañés, también llamado castoreño, en la cabeza, así como varios en el suelo a su alrededor; los dedos desnudos; $\mathrm{y}$ un ambiente de animados acompañantes tocando las palmas, golpeando un pandero y rasgando una guitarra, constituyen la imagen habitual de este tipo de bailes. Estas composiciones se alternan en espacios diversos, que si bien se producían habitualmente en los escasamente iluminados salones de las academias y en otros alquilados para la ocasión, lo cierto es que los bailes de jaleos fueron representados mayoritariamente en entornos naturales, bien en romerías o ferias, o bien en paradas del camino con ventas, mesones o patios de cortijos o corrales. En cualquier caso, lo cierto es que no existe una clara identificación pictórica entre los espacios representados y los reales de consumo, pues en la mayoría de los casos fue en salones particulares. Por ello, en este aspecto concreto domina la influencia ejercida por la literatura de viajes, que previamente a la aparición de este género pictórico, ya había creado toda una serie de referencias espaciales que resultaron eficaces.

Estos espacios que se identificaron como propios de la vida de los españoles en sus aspectos más pintorescos, posteriormente serían recogidos por la pintura de bailes. Las paradas en el campo durante las romerías, las ferias, los diáfanos salones de las ventas o sus emparrados se convirtieron en un atractivo especial por tratarse de un aspecto ya reconocido. Son pocas las imágenes que escapan a este dictado que marca la literatura con sus espacios pintorescos, destacando el Salón de baile de Manuel Cabral Aguado Bejarano que se encuentra en el Museo de Bellas Artes de Sevilla, o la Fiesta Andaluza también del mismo pintor, en la que repite también un interior similar, perteneciente a una colección privada, así como el óleo de la Fiesta en un interior de Francisco Gualtari de 1863 (Figura 4).

Los bailes de jaleo contenían una serie de características que marcaban su ritmo frenético como eran los zapateados en los que destacaban figuras como el matalaraña o el mata la curiana, como se conocía en Sevilla; la alternancia de momentos de elevada excitación física con estados de total relajación en posiciones erguidas, combadas o incluso tendidas sobre el suelo; el salto para bailar sobre una mesa; o el juego con determinadas prendas con las que se construía el baile, como son el sombrero y el pañuelo. Estos elementos provocaban determinadas posiciones que generaban imágenes sumamente elocuentes, como son los casos del levantamiento de la falda con las manos para iniciar el zapateado acelerado del matalaraña; el sombrero castoreño ladeado sobre la cabeza como prueba de aceptación al final del baile o bien en la mano como elemento de juego; la elevación de la bailarina sobre una mesa hasta colocar sus pantorrillas a la altura de los espectadores y el amontonamiento de sombreros calañeses o castoreños a sus pies. Estos pasos generarían imágenes que se codificarían hasta convertirse en iconografías propias de estos bailes, como son los casos del olé, el vito o los jaleos, entre ellos el famoso jaleo de Jerez.

Las imágenes, por tanto, que en pintura se crearán para diferenciarlos de los pasos boleros, con los que comparten espectáculo desde 1845 en las academias y 
salones, son las siguientes: la bailarina levanta ligeramente su falda con una de sus manos o bien con las dos mostrando las enaguas; se representa ataviada con un sombrero calañés ladeado en la cabeza y con los manos despojadas de cualquier tipo de instrumento musical, a sus pies aparecen diversos sombreros masculinos dispersos. A estos elementos se le añade la posibilidad de disponerse subida a una mesa. En este último caso se prescinde de los sombreros a los pies, como ocasionalmente de su complemento en la cabeza. Ambas imágenes representan a los dos bailes flamencos más populares de estos años que median entre $1840 \mathrm{y}$ toda la década 1860: el olé y el vito. A ellos responden algunas pinturas tan tempranas como el óleo de Joaquín Domínguez Bécquer, El baile en una posada, fechado en 1844, y también en esta década, Una bolera bailando el vito, de la colección Orleans de Sanlúcar de Barrameda, fechada en 1848, y el Baile andaluz de Manuel Rodríguez de Guzmán, de Patrimonio Nacional, fechado en 1848. A partir de esta fecha la producción se multiplica haciendo de la década de $1850 \mathrm{su}$ periodo más importante.

A lo largo de estos años las producciones más relevantes y numerosas salen de los pinceles de Manuel Rodríguez de Guzmán y de Joaquín Domínguez Bécquer. El primero ofrece la producción más prolífica de estas composiciones durante los años de 1850; concretamente, algunas de las obras más relevantes son de su producción, como las fechadas en 1854, caso del Baile en una venta; el Baile en la taberna, del Museo de Bellas Artes Sevilla; o La Feria de Santiponce, ya de 1855, del Museo del Prado. Entre las producciones de Joaquín Domínguez Bécquer destaca la Escena en un mesón, de 1855, de una colección particular en Sevi1la. De igual forma, de Rafael Benjumea tenemos el Baile en una venta, de 1850, de la colección Thyssen-Bornemisza, y de Manuel F. Barrera, Danza en un interior, de 1854, de una colección particular. Entre ellos es necesario incluir La feria de Sevilla, de Andrés Cortés, en sus dos versiones de 1852, tanto la del Museo de Bellas Artes de Bilbao como la de una colección particular de Sevilla. Estas dos últimas composiciones de Cortés resultan especialmente significativas para el género, pues el baile aparece inserto en medio de una extensa y compleja composición como parte de la misma, precisamente en un momento en el que su difusión se estaba consolidando (Figura 5).

Dentro de la producción de Rodríguez de Guzmán sobre bailes de jaleos, destacan también por la relevancia de su composición dos obras no fechadas, localizadas en colecciones particulares, posiblemente realizadas dentro de este marco cronológico, como son El baile del farol y Por fandangos en la taberna. Y, ya en la década de 1860, dos obras: el Baile en una venta, de Joaquín Domínguez Bécquer, de 1867, en la colección Carmen Thyssen-Bornemsiza, con una composición singular por la ubicación lateral y el tamaño menor conferido al grupo de baile dentro del paisaje; y el Interior de una posada, de 1860, de Manuel Rodríguez de Guzmán, en una colección particular de Sevilla. Sabemos que todas ellas representan bailes de jaleos, pero la cuestión se complica cuando pretendemos 
distinguir exactamente cuál de estos bailes aparece representado en las pinturas, ya que algunos de estos pasos, ademanes, giros o posturas, según diversos testimonios contemporáneos, se podían dar en bailes diferentes. Sin embargo, podemos asegurar que en la pintura serían dos los que aparecen representados principalmente: el olé y el vito. A este se suma un tercero que apenas tiene difusión en la pintura de costumbres, aunque tuvo mucha repercusión escénica gracias a la bailarina francesa Marie Guy-Stéphan que lo consagró en el teatro del Circo de Madrid el 28 de enero de $1845^{32}$.

Uno de los elementos más importantes de la iconografía de estos bailes es el sombrero castoreño, pieza indispensable tanto en el olé como en el vito, según la memoria de numerosos viajeros que recorrieron Sevilla en estas fechas. Si repasamos los testimonios de algunos de ellos, descubrimos que se utilizaba indistintamente tanto en el olé como en el vito. No obstante, de igual forma, encontramos interpretaciones de ambos también sin ellos. En cualquier caso, si repasamos las fuentes literarias que conservamos procedentes de las memorias de clientes de estas fiestas en la ciudad desde 1845 para establecer las relaciones oportunas con las pinturas concebidas por los artistas locales de este tiempo, destacan cuatro testimonios como referencia. Entre 1845 y 1847, fechas entre las que se insertan las primeras representaciones de composiciones de bailes de jaleo, los escritores Terence Hugues, Alejandro Dumas, Dora Wordsworth y Severn Teackle Wallis nos dejan importantes testimonios. Concretamente, el encuentro entre el olé y ellos se produce en el caso del francés Hugues en $1845^{33}$, en el de la británica Wordsworth en abril de $1846^{34}$, en el del francés Dumas en otoño de $1846^{35}$ y en el del estadounidense Wallis en mayo de $1847^{36}$. Además, se da la circunstancia de que las bailarinas que participaron en las fiestas y exhibiciones son algunas de las más destacadas del panorama no solo local sino internacional, como son los casos de Petra Cámara y su hermana Ana en el caso de Dumas, o de Amparo Álvarez "la Campanera" en el de Wallis. Al que se sumarían las dos bailarinas de Hugues, Jacinta y Rubí, y Carmen Callejo del teatro Principal con Dumas ${ }^{37}$. Por ello, entre

${ }^{32}$ HORMIGÓN, Laura: Marius Petipa en España. 1844-1847. Madrid, 2010, pp. 171189; y PLAZA ORELLANA, Rocío: Los bailes españoles..., op. cit., pp. 226-309.

${ }_{33}$ HUGUES, Victor Aimée: Revelations..., op. cit., vol. 1, pp. 413-419.

${ }^{34}$ WORDSWORTH, Dora: Journal of a few months residence in Portugal and Glimpses of the south of Spain. Vol. 2. Londres, 1847, p. 108.

${ }^{35}$ DUMAS, Alejandro: De París a Cádiz. Madrid, 2002, pp. 528-529.

${ }^{36}$ WALLIS, Severn Teackle: Glimpses of Spain; or Notes of an Unfinished Tour in 1847. Nueva York, 1849, pp. 186-188.

${ }_{37}$ AMS (Archivo Municipal de Sevilla), secc. 14, 1846, folleto ${ }^{\circ} 16$. El baile que presencia Alejandro Dumas lo organiza la redacción del periódico La Jiralda en la academia de bailes de Miguel de la Barrera. Lo harían contando con algunas bailarinas que había conocido previamente en una función que el teatro organizó para él días antes, y contaría a sus lectores que en esta fiesta particular participaron algunas de las artistas que vio en 
1845 y 1847, tenemos un recorrido documental del olé a través de importantes bailarinas tanto internacionales como locales.

En las descripciones que nos ofrecen estos escritores tenemos que realizar una importante diferencia: la que establece el espectáculo que se prepara para mujeres como describe la escritora británica, y aquel en el que acuden solo hombres, como son los otros tres casos. Si bien los cuatro contemplan un olé, lo cierto es que se trata de un baile que por la sensualidad de su naturaleza resultaba extremadamente versátil, por lo que, dentro de los códigos morales del público que los contemplaba, la idoneidad de la asistencia de las mujeres a algunos espectáculos quedaba reducido a unos límites y códigos determinados. Por este motivo, el olé que presencia Dora Wordsworth, también ofrecido por las bailarinas del teatro Principal, con bastante probabilidad por el mismo elenco que conocería Dumas, nos habla de unas formas sensuales aunque interpretadas por jóvenes de corta edad, y con movimientos más contenidos; incluso recoge dentro de este baile, que ella denomina "baile del pañuelo gitano", la característica que más le sorprende, que realmente es una variante que se ofrecía en los bailes preparados para extranjeras en las academias. Dora nos cuenta sobre este baile, que según le informa su guía: "las bailarinas esperaban alguna pequeña ofrenda en estas ocasiones de los caballeros de la fiesta y la forma en la que se manejaban era la siguiente. Mientras se baila el baile del pañuelo gitano, la dama deja caer su pañuelo a los pies de cualquier caballero que haya seleccionado; este lo recoge, ata un pedazo de dinero en una esquina y le devuelve el pañuelo a la señorita cuando sale de la habitación" 38 .

El olé se bailaba con un sombrero calañés, y esta petición de dinero se hacía con él normalmente, aunque el juego que provocaba entre los hombres el manejo de este complemento parece que se dejaba reservado solo a funciones con un público masculino. En cualquier caso, no sería esta variante del pañuelo la que se codificaría en la pintura para estos bailes, sino la del sombrero calañés o castoreño que son precisamente las que disfrutarían los otros tres escritores.

Las variantes del olé son muchas, pues el baile que irrumpió en la escena a principios del siglo XIX en Sevilla alcanzó una gran popularidad durante el periodo isabelino, y continuó su curso con diferentes modalidades por las academias de baile hasta desembocar en las primeras décadas del siglo XIX. No obstante, los que presenciaron la mayoría de los viajeros entre 1845 y 1860 coinciden en sus elementos principales, que son los que se trasladarán a la pintura de este momento, y constituyen también los que Hugues, Dumas y Wallis disfrutaron en estos años fundamentales para el género pictórico y coreográfico de finales de la

el teatro. Listado de la compañía de baile al que corresponde el documento citado, que ha servido para identificarlas.

${ }^{38}$ WORDSWORTH, Dora (Mrs. Quillinan): Journal of a few months..., op. cit., vol. 2, p. 108. 
década de 1840. Terence Hugues, en 1845, conoció a Rubí bailando el olé en un patio de una casa de Triana dentro de una función que habían preparado para extranjeros, y nos cuenta que una de sus partes más características llegó al final, cuando en un grito al unísono de los hombres que acompañaban al baile con las palmas y jaleando gritaron "¡Olé!”. En ese momento: “Cerca de una veintena de sombreros de las cabezas de sus admiradores volaron hacia el suelo, y ella se inclinó y pisó con sus pies triunfantes. Esta parte es indispensable, mientras que cien voces gritaban Olé. Todos se encontraban en un torbellino de furor y de deleite" 39 En otra ocasión vería bailar a Jacinta la de Salvador, a la que consideraba "la mejor bailarina de Sevilla" porque aseguraba que "destruyó más sombreros que cualquier otro pie de Andalucía", ya que "los mismos músicos solían arrojar su sombrero para ser pisoteados en su conclusión triunfante del baile" 40 .

Alejandro Dumas lo vería bailar a Anita, hermana de Petra Cámara ${ }^{41}$, y contaría que Anita tomó el sombrero del hombre que tenía más cercano, y comenzó a bailar con él, entonces "comienza por colocarlo en su cabeza de todas las formas posibles: ladeado como un petimetre del Directorio; hacia atrás, como un inglés; sobre la frente, como un académico. Anita tenía entonces ese sombrero con el que se cubría de todas las maneras posibles, luego de tiempo en tiempo alzaba ese sombrero de su cabeza y avanzaba hacia uno de nosotros como para ponerlo sobre la suya. Pero al primer movimiento de aquel que parecía favorecido, Anita giraba sobre sí misma, y de un salto se encontraba al otro lado del círculo, dirigiendo la misma coquetería a algún otro que acabaría por ser embaucado como su predecesor; y ante cada nuevo engaño de esta clase, madame, eran risas, gritos, aplausos, bravos como para tirar abajo la sala, lo cual era justo" ${ }^{2}$. Finalmente lo colocaría sobre la cabeza de Dumas.

Al año siguiente, en mayo de 1847, el estadounidense Severn Teackle Wallis lo vería bailar a Amparo Álvarez "la Campanera" en una fiesta privada organizada para ingleses y huéspedes de la Fonda de Europa. Wallis contaría también que a la bailarina le arrojarían los sombreros al suelo a su paso, "como extendían las capas Raleigh ante Elizabeth" ${ }^{4}$. De igual modo contaría el juego que ella practicó bailando con los diferentes hombres de la sala, simulando que les colocaba su sombrero calañés mientras ellos se quitaban el suyo y lo arrojaban a los pies, en un juego de seducción amoroso que terminaba con los sombreros por el suelo, aunque ella colocaba el suyo sobre la cabeza del que finalmente había elegido. En definitiva, para los extranjeros la parte más llamativa del baile se identificaba precisamente con los juegos establecidos con el sombrero entre la bailarina

\footnotetext{
${ }^{39}$ HUGUES, Terence: Revelations..., op. cit.. vol. 1, p. 419.

40 Ibidem, p. 403.

${ }^{41}$ PLAZA ORELLANA, Rocío: Los bailes españoles..., op. cit., pp. 151-153.

${ }^{42}$ DUMAS, Alejandro: De París..., op. cit., p. 528.

${ }^{43}$ WALLIS, Severn Teackle: Glimpses of Spain..., op. cit., p. 186.
} 
y los hombres como señal de coqueteo, así como la colección de ellos que terminaba a sus pies, sobre los que podía pasar por encima como señal de triunfo. Esta es la imagen que sería plasmada mayoritariamente de este baile. Y es la que apreciamos en la mayoría de las pinturas de bailes de este momento, como es el caso de Baile andaluz de Manuel Rodríguez de Guzmán, de Patrimonio Nacional, fechado en 1848.

Cuestión diferente representa el vito. Si bien sus similitudes musicales y coreográficas con el olé impidieron a muchos extranjeros diferenciarlos, como reflejan los diversos testimonios de este periodo, incluido el de Alejandro Dumas, sin embargo existe una particularidad que ocasionalmente podía tener, y que sería recogida en la pintura. Se trata de la modalidad de baile sobre una mesa, es decir, que la bailarina subía sobre la mesa y realizaba todos los zapateados entre los vasos de los espectadores y el golpeteo de las manos de los hombres.

El vito compartía con el olé el juego del sombrero con los hombres de la sala, es decir, la bailarina terminaba igualmente con los sombreros por el suelo, aunque como escribe Dumas ${ }^{44}$, se incluía también el del hombre que había escogido, el cual terminaba pisado como señal de triunfo. Por este motivo el vito aparece también representado con estos mismos recursos, como es el caso por ejemplo de la pintura de Joaquín Domínguez Bécquer Una bolera bailando el vito, de la colección Orleans de Sanlúcar de Barrameda, fechada en 1848, cuando se trata de un baile sobre el suelo; pero cuando se realiza sobre la mesa, el recurso de los sombreros desaparece de la pintura, no más allá de la colocación del castoreño sobre la cabeza de la bailarina si el pintor lo considera oportuno. Los casos más significativos de este baile sobre la mesa son los de El baile del farol de Manuel Rodríguez de Guzmán, de una colección particular, sin sombrero, o el de Danza en un interior de Manuel F. Barrera, de una colección particular, de 1854, con sombrero. Estas son las particularidades del olé y el vito, los bailes más representados en la pintura de costumbres de este periodo, y más consumidos por los extranjeros en sus fiestas también en este momento (Figuras 6-8).

No obstante, resulta importante distinguir que estas son sus formas especialmente en su momento inicial, concretamente entre 1844 y 1850, ya que ambos evolucionarán considerablemente, aumentando la confusión en sus pasos entre sus espectadores, así como también su posible identificación en la pintura, al servirse de recursos, que si bien eran propios de cada uno originalmente, dado su éxito en las fiestas, los compartirían ambos, codificándose en la pintura hasta resultar muy difícil su diferenciación.

Fecha de recepción: 30 de octubre de 2018

Fecha de aceptación: 1 de julio de 2019

${ }^{44}$ DUMAS, Alejandro: De París..., op. cit., pp. 529-530. 


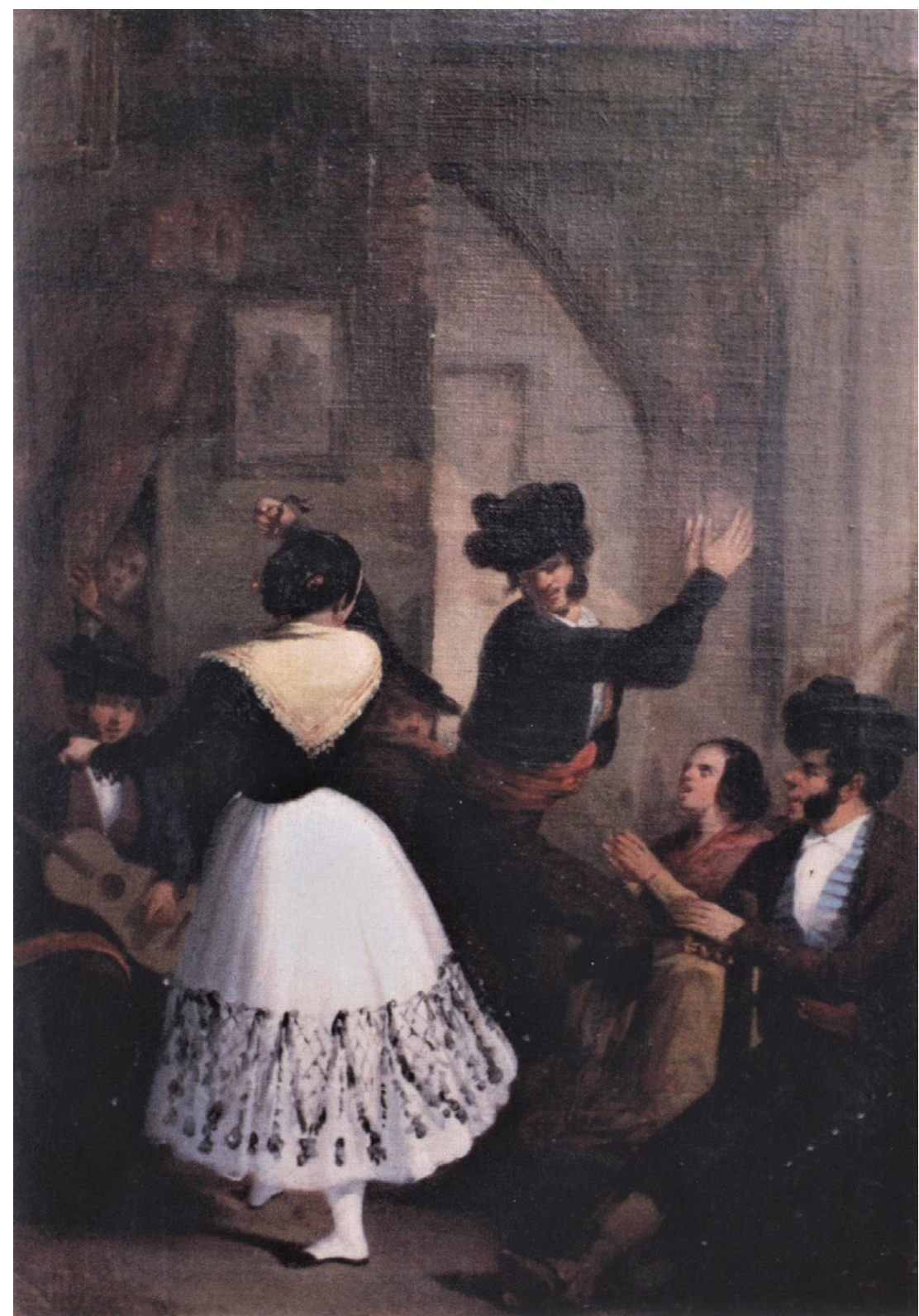

Figura 1. Joaquín Domínguez Bécquer, Baile en una bodega, 1844, colección particular. 


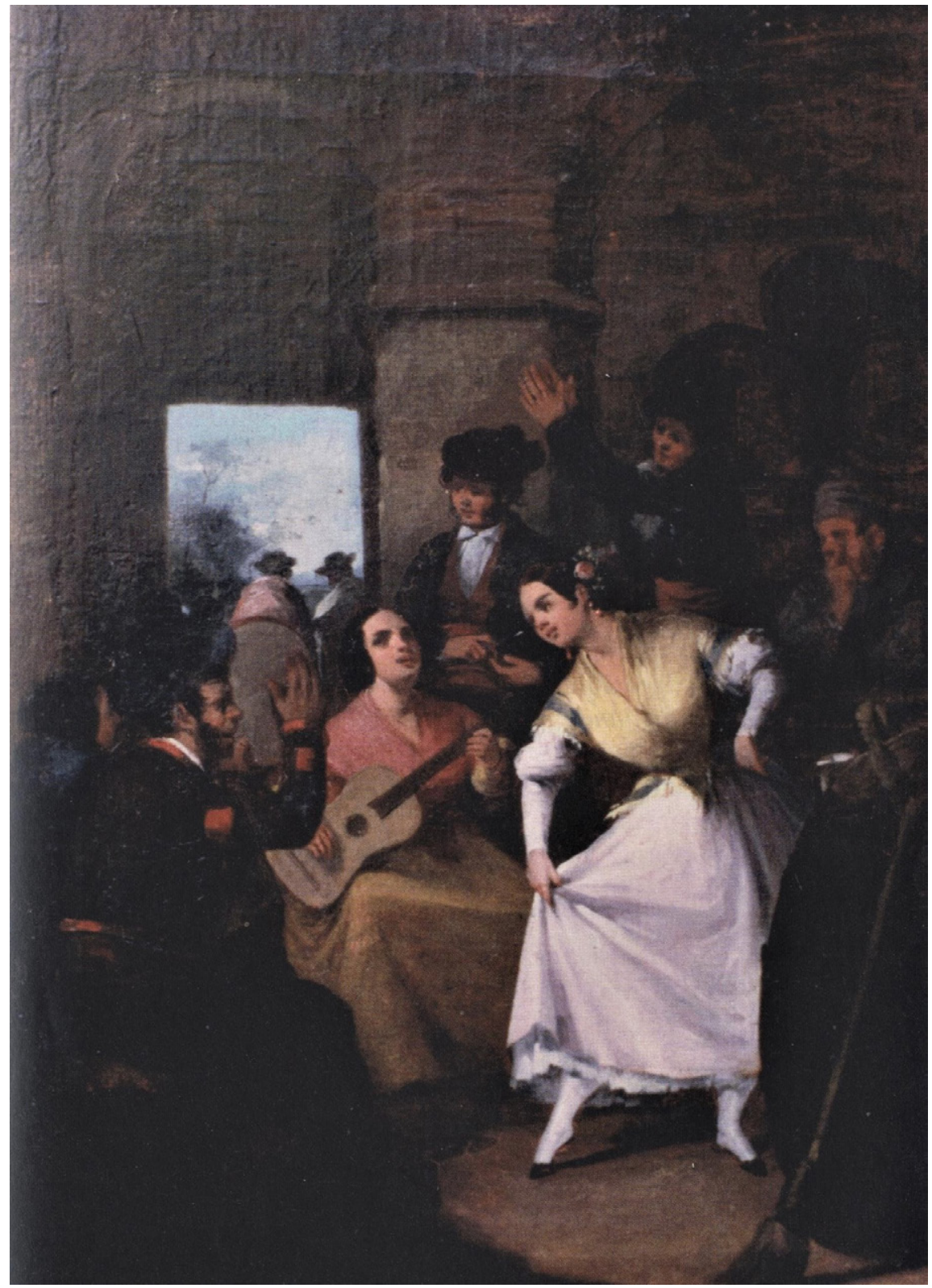

Figura 2. Joaquín Domínguez Bécquer, Baile en una posada, 1844, colección particular. 


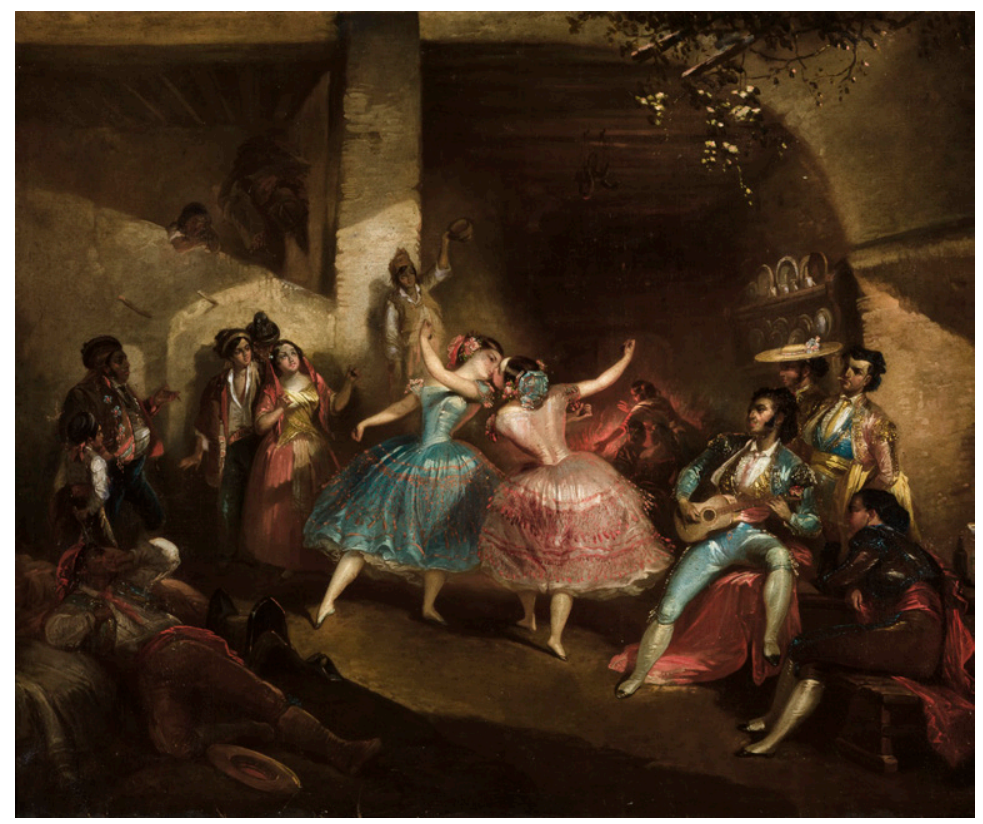

Figura 3. Manuel Rodríguez de Guzmán, Bolera del beso, Museo de Bellas Artes de Sevilla.

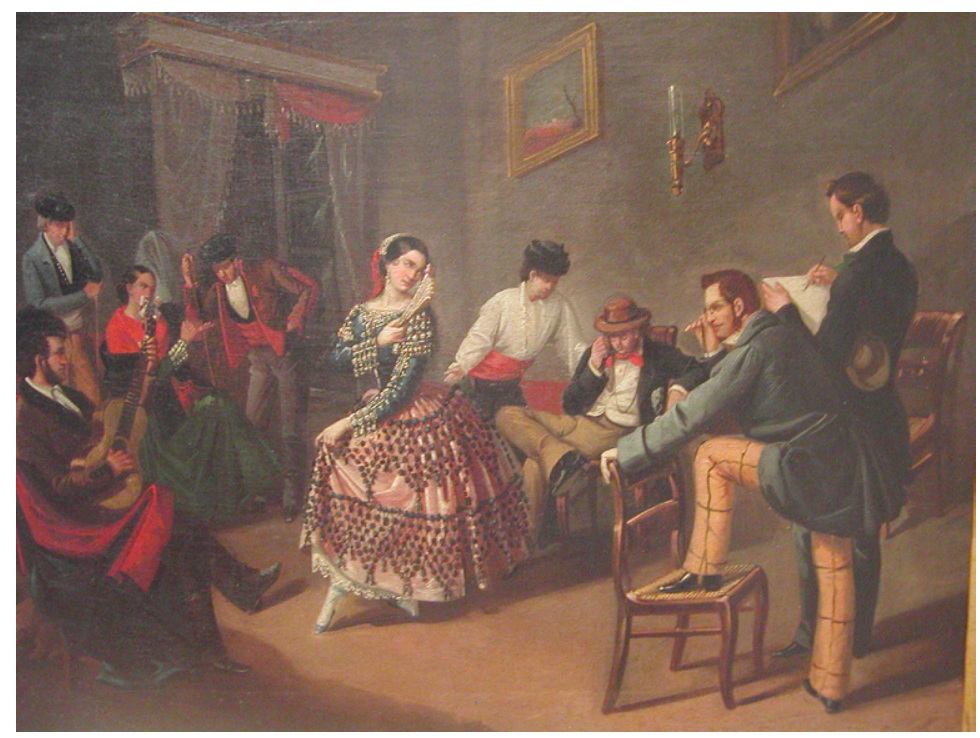

Figura 4. Manuel Cabral Bejarano, Baile en un salón, Museo de Bellas Artes de Sevilla

LABORATORIO DE ARTE 31 (2019), pp. 537-560, ISSN 1130-5762 e-ISSN 2253-8305 - DOI http://dx.doi.org/10.12795/LA.2019.i31.31 


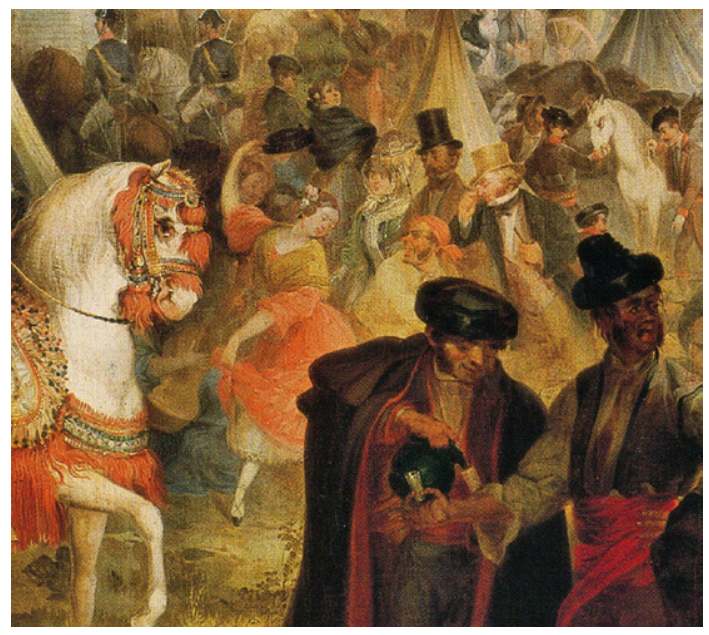

Figura 5. Andrés Cortés, La feria de Sevilla (detalle), 1852, Museo de Bellas Artes de Bilbao.

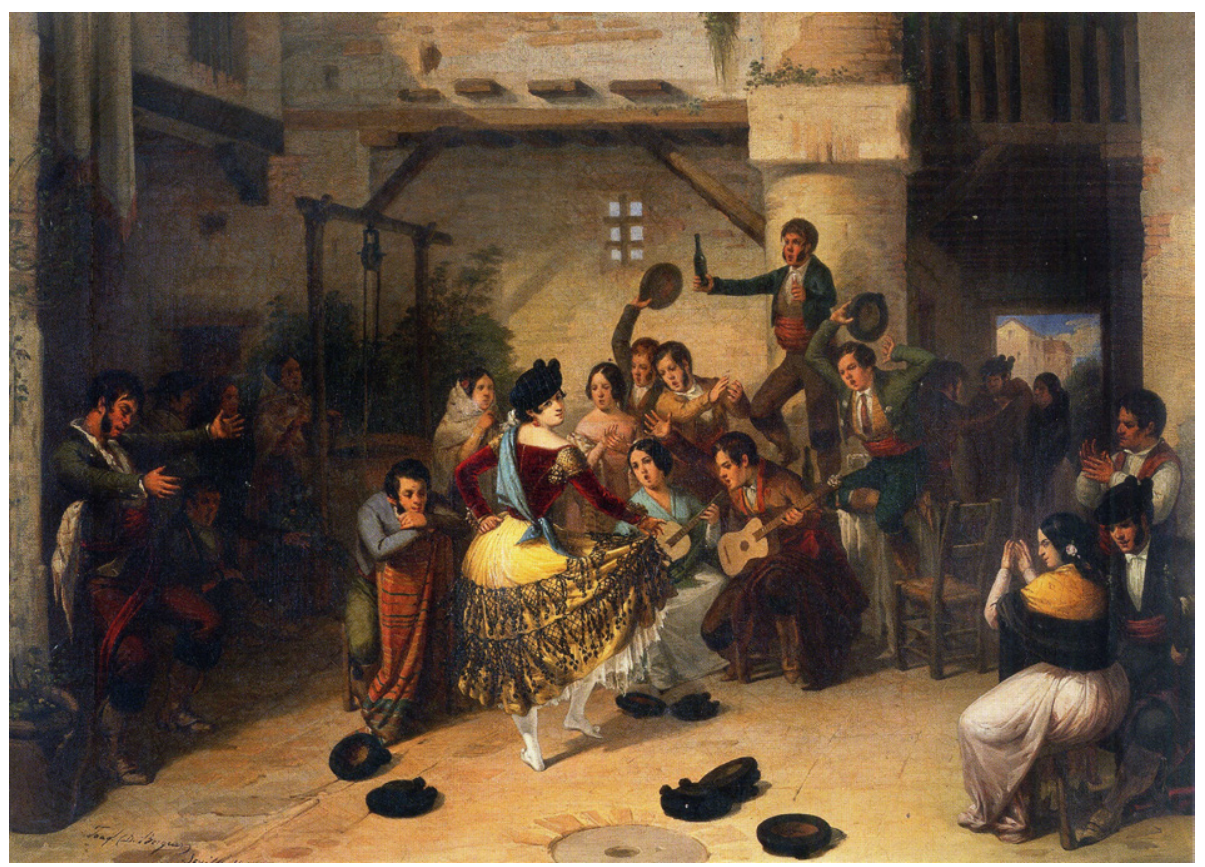

Figura 6. Joaquín Domínguez Bécquer, Bolera bailando el vito en un mesón, 1848, colección Orléans de Sanlúcar de Barrameda (Cádiz) 


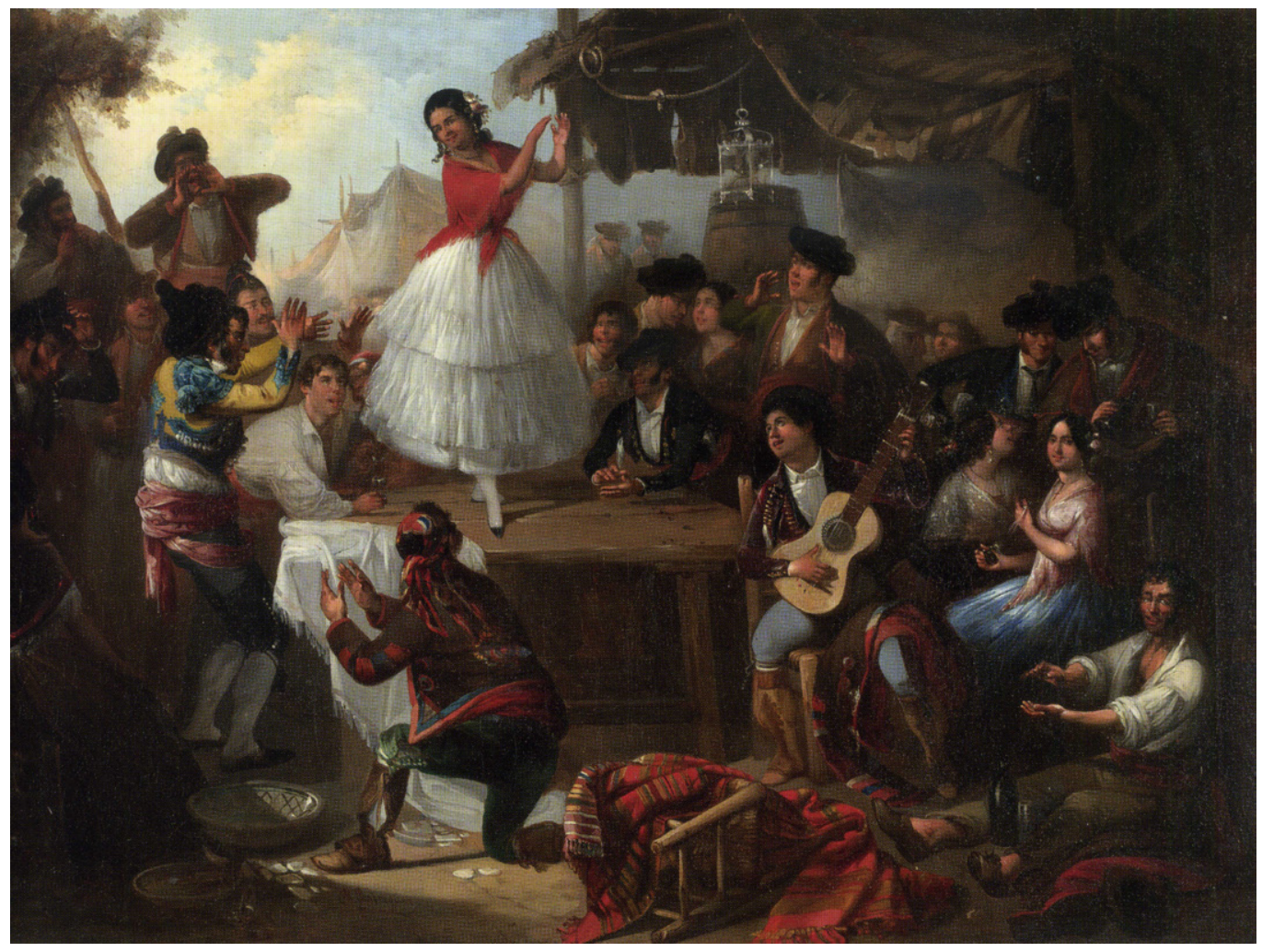

Figura 7. Manuel Rodríguez de Guzmán, El baile del farol, colección particular. 


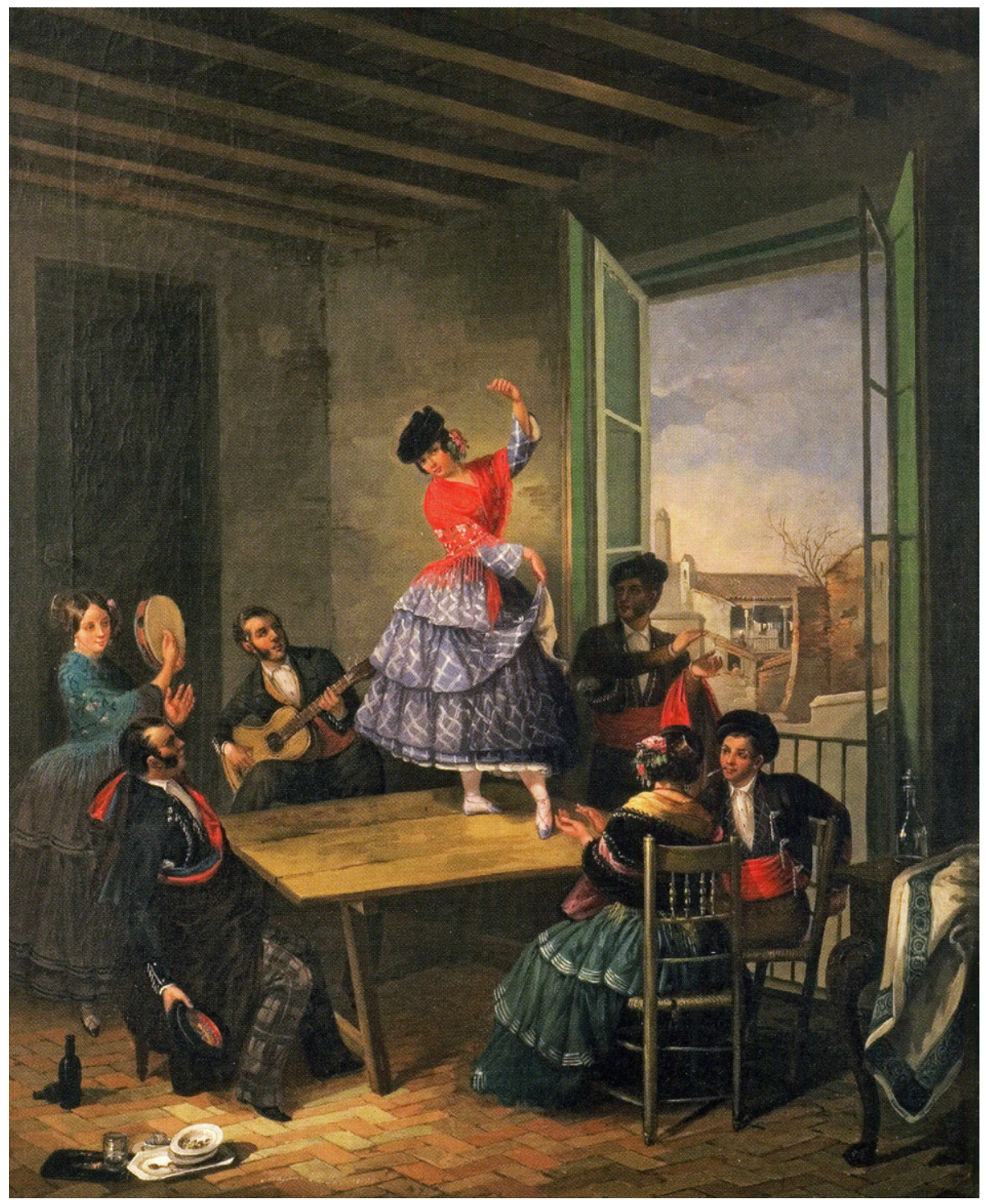

Figura 8. Manuel F. Barrera, Danza en un interior, 1854, colección particular. 